\title{
A Conceptual Study of HRM Practices and Market Orientation on Lecturer's Retention: A Case Study of Malaysian Universities
}

\section{Zuhaib Hassan Qureshi}

PhD Candidate, University Kuala Lumpur Business School, University Kuala Lumpur, Malaysia

\section{Hussam Al Halbusi}

PhD Candidate, Department of Business Strategy and Policy, Faculty of Business and Accountancy, University of Malaya, Kuala Lumpur, Malaysia

\section{Sheena Pitafi}

$\mathrm{PhD}$ Candidate, Department of Management Technology, Mehran University of Engineering and Technology, Jamshoro, Pakistan

\section{Shehnaz Tehseen}

Lecturer, Department of Management, Sunway University Business School, Sunway University, Malaysia

\begin{abstract}
Nowadays human resources are focused more to gain competitive advantage. Human resource practices are used for staffing and keeping employees, but they alone are not enough. Good human resource management practices do not work unless the universities get all possible information about their customers and competitors in their competitive market environment. Since the competition worldwide becomes so high, organizations, universities, institutes require strong teams and those teams in each place should be highly committed. This is a conceptual paper based on the past literature review and underpins theories to discuss the impact of the selected human resource factors and organizational factors on retention of core lecturers of Malaysian private universities. The main purpose of this paper is to suggest and develop a new framework that emphasizes the reducing turnover intentions by taking into consideration the components of market orientations, which include customer analysis and competitor analysis. This paper will help the policymakers, the human resource personnel to develop better human resource policy to retain the core employees.
\end{abstract}

Keywords: human resource practices, market orientation, turnover intention, core lecturers, private universities.

\section{JEL Classification: J24, M31, J63.}

(C) The Authors, 2018. This article is published with open access at Sumy State University.

\section{Introduction}

In the modern social era of globalization where every organization strives to be competitive in the market, different strategies and practices have been used in such organizations to get a competitive edge. Nowadays human resources are focused more to gain competitive advantage. Especially for the education industry, which depends mainly on the knowledge of its people, managing its employees become more essential as these knowledge workers are actually drivers of the education industry. It is even very critical for private universities to manage and keep their core lecturers who work under pressure to deliver high-quality education according to the demand of students.

Human resource practices are used for staffing and keeping employees, but they alone are not enough. Good human resource management practices do not work unless the universities get all possible information about their customers and competitors in their competitive market environment. The market orientation, which focuses on customer needs and competitors' actions, becomes an essential need of all universities. Through market orientation, a university can develop and implement good human resource management practices to retain its core lecturers.

Most of the researches into market orientation have basically been carried out in manufacturing industries with respect to external customer orientation and competitor orientation to enhance organizational performances. As far as the educational industry is concerned, a very little study has been conducted in public and private universities with respect to market orientation that mainly focuses on customer orientation (student's needs). 
As far as we know, none in the context of Malaysian private universities is concentrating on internal customers. Whereas human resources provide a competitive advantage to organizations, thus sustainable competitive advantage can be achieved through focusing on employees of organizations through market orientation as well. Researchers have revealed that human resource management practices help to retain key lecturers of private universities (Darougheha et al., 2013; Hong et al., 2012; Rosdi and Harris 2011), but these HRM practices become less effective without considering market orientation.

Through market orientation, private universities may assess the needs of lecturers and then also by benchmarking with their competitors, they can develop more effective HRM practices to retain their core lecturers. According to Harris and Ogbonna (2001), many theorists and practitioners realized the need for further research to explore the barriers and processes of market orientation development and they note the relative shortage of research into such antecedents. In the last few decades, researchers have studied several antecedents of market orientation in order to have a better understanding of its role in organizations. A business is market orientated only when the entire organization adopts the values implied therein, and when all business processes are directed at generating outstanding customer value (Slater, 2001).

This idea is of greater importance in non-manufacturing companies such as service companies, where human resource practices have a greater impact on market orientation than in manufacturing firms because of the greater dependence on person-to-person interactions that overcome in the service sector (Singh, 2000; McNaughton et al., 2002). According to Mavondo et al. (2005), investment in HR practices influences the processes of creating customer value; through the attraction, selection and retention of high-quality employees, providing appropriate skills. In that respect, Mavondo et al. (2005) indicate that marketing research must consider integrating human resource practices in models of market orientation as this provides a comprehensive presentation and adds realism to such models. Both market orientation and human resource practices impact positively on the processes of creation of value to the customer. Thus an employee retention phenomenon can be studied under these research streams as well. Because according to Mavondo et al. (2005), in the academic literature, both research streams have been developed along parallel tracks in spite of the recognition of links in these areas. Therefore, this work aims to contribute to an integrated vision of both stream pieces of research, especially in the area of employee retention.

Furthermore, it is important to consider how the antecedents of market orientation impact different sectors of activity. In that respect, Kirca et al. (2005) prove that the existing literature needs a better understanding of how the influence of the antecedents of market orientation differs in different business and cultural contexts. Thus, further research should determine profiles of best practices to implement market orientation in different cultural contexts.

This study is justified by the absence of research in the education sector and the importance of studying the interrelations between market orientation and human resources in the education industry. In that respect, this research work seeks to study the extent to which human resource management is an antecedent of market orientation in the education sector. More specifically, this work aims to identify the impact of the policies for recruiting, training, career development, and compensation issues exercise on the different dimensions of market orientation.

According to MOHE (2013), there are 414 private colleges, 37 private universities, 20 university-colleges and 7 foreign branch campuses in Malaysia. Malaysia is the world's 11th largest exporter of educational services with over 90,000 international students from over 100 nations studying at its educational institutes. Malaysia's overall higher education sector is ranked 14th out of 142 countries. In 2011, the Higher Education Ministry set a target of attracting 85,000 international students to the growing number of private education institutions but surpassed this by achieving a 93,000 international student enrollment rate.

The higher education ministry of Malaysia aims to earn RM6 billion through a projection of 200,000 international students in the country by 2020 . The earnings projection was based on an average of RM30, 000 per student. The Malaysian government is experiencing on the increased demand for quality education of students. Malaysia earns about RM4 billion per year. 2\% (market) of total international students are studying in Malaysia that is relatively low.

A problem in any organization is that the core employees have a major contribution in achieving its goals by utilizing their capabilities and skills. Thus, every organization strives to keep its best and talented employees, but that's not so easy due to the competitive business environment where every competitor tries to poach the 
best employees of its rival organization. However, employee's retention factors are problems for any organization and have to be studied (Van Berkel et al., 2017; Ambrosius, 2018).

The key employees also look for better employment opportunities in their relevant industry. Once they get more suitable jobs than they leave their organization and switch to a better one. The turnover of key employees is becoming a major challenge for every organization. In Malaysia, not only a manufacturing sector is facing this problem, but also non-manufacturing sectors are having this issue. For instance, the Table 1 and Fig. 1 below shows that the average turnover rate for the education sector was $29.28 \%$ from July 2010 to June 2011. It has been ranked in the third place after IT/ communication sector and hotel/ restaurant sector, according to the study conducted by Kelly Services' in Singapore and Malaysia.

Table 1. Statistics for the average turnover rate of non-manufacturing sectors in Malaysia from July 2010 to June 2011

\begin{tabular}{|ll|}
\hline \multicolumn{1}{|c|}{ Non-Manufacturing Sector } & Annual Average \\
\hline Banking/Finance/ Insurance & $\mathbf{1 2 . 1 2 \%}$ \\
\hline Business Service & $\mathbf{1 5 . 7 2 \%}$ \\
\hline Education & $\mathbf{2 9 . 2 8 \%}$ \\
\hline Holdings and Investment/ Plantation & $\mathbf{1 7 . 4 \%}$ \\
Hotel/ Restaurant & $\mathbf{3 2 . 4 \%}$ \\
IT/ Communication & $\mathbf{7 5 . 1 2 \%}$ \\
Medical Service & $\mathbf{1 9 . 8 \%}$ \\
Property/ Construction & $\mathbf{1 5 . 6 \%}$ \\
Transport/Warehouse Service & $\mathbf{2 6 . 8 8 \%}$ \\
\hline Wholesale/ Retail/ Trading & $\mathbf{1 8 \%}$ \\
\hline
\end{tabular}

Source: Malaysian Employers Federation (MEF)

The Malaysian private universities are facing the major challenge of retaining their core lecturers due to their high turnover issues. This also indicates that Malaysian universities are facing critical "brain drain" phenomena. The problem of turnover has been highlighted in many previous research studies as well in the context of Malaysia. For instance, according to Amin (2002), high turnover rates were recorded over a threeyear period in one of the private universities in Kuala Lumpur. The turnover rate in the private university of Kuala Lumpur was 14 percent in 1997, 28 and 37 percent in 1998 and 1999 respectively. Other researchers such as Siron (2005) and Morris et al. (2004) also indicated that the Malaysian government had often expressed its concern about the high turnover of academics in higher education institutions in Malaysia, primarily from private universities. Thus, private universities are facing great challenges of academic staff turnover, which acts as an obstacle in achieving the vision of 2020 regarding human capital development, world-class ranking among world's universities and colleges as well as an international standard and quality in higher education.

The project aims to uncover employee retention practices that are implemented by private Universities in Malaysia. In details, the researcher would like to answer the following questions:

$>$ Is there a relationship between Human Resource Management (HRM) practices and organizational factors and retention? And which human resource factors and organizational factors mostly influence the decision of academic staff to stay?

$>$ Who are the core lecturers and do they have different needs to another type of employees?

$>$ How does market orientation mediate the impact of human resource factors and organizational factors on retention of core lecturers?

$>$ Is the importance placed on market orientation by private universities to formulate lecturer's retention strategies?

$>$ How are human resource factors and organizational factors managed in the private universities by considering the market orientation? And how do these differ from non-core lecturers?

The current study attempts to enhance our understanding and improve the shortage of retention literature. Based on the research questions, the main research objectives can be summarized as follows:

1. To determine the relationship between human resource management practices and retention as well as between organizational factors and retention and then to assess the most influential factors among human resource factors and organizational factors that impact retention decision.

2. To identify the characteristics of core lecturers and their needs. 
3. To investigate the importance placed on market orientation in relation to human resource factors and organizational factors for retaining core lecturers.

4. To examine the role of market orientation in formulating retention strategies.

No one of empirical studies has been conducted in the past to provide the Ministry of Higher Education with a sustainable remedy to the problem of lecturer's retention in private universities, particularly in the Malaysian context.

The private universities are facing challenges in determining the factors that are instrumental in improving retention amongst talented employees. The present study will identify and establish key motivational variables that most influence retention in the Private universities. The outcome of the study will significantly advance the frontier of knowledge and add to the existing academic literature on retention regarding key lecturers within private universities. The findings will also be useful in the formulation of effective retention policies and in reviewing existing ones. It is believed that the results of the study will inspire other researchers to investigate further areas that are not covered in this study.

\section{Literature Review}

\subsection{The Human Resource Management Practices and Employee Retention}

The human resource practices include recruitment and selection, training and development, performance management, remuneration systems, effective communication, employee empowerment and involvement, teams and teamwork (Oakland and Oakland, 2001; Jackson and Schuler, 1995). Many theoreticians made the argument that the human resources of the company are the only source of competitive edge for the organizations (Becker and Gerhart, 1996; Wright, McMahan and McWilliams, 1994; Ferris et al., 1999, Pfeffer, 1996).

According to Pfeffer (1998), a human resource system helps to create a competitive workforce whose contribution and performance are valuable, unique and difficult for competitors to imitate. Many academic researchers conducted at the organizational level also revealed that human resource practices affect outcomes of organizations by shaping employee behaviours and attitudes (Arthur, 1994; Tsui, Pearce, Porter and Tripoli, 1997).

According to many studies on retention, the retention management is a strategic and coherent process that begins with the inspection of the reasons that employees join an organization (Davies, 2001; Fitz-en, 1990; Solomon, 1999). Many other studies suggest that high-involvement work practices will enhance the employee retention (Arthur 1994, Koch and McGrath, 1996). Studies have revealed that human resource management practices, training, compensation, reward, typical employee benefits can lead to reduced turnover and absenteeism, better quality work, improved financial performance and increased retention (Arthur, 1994; Delaney and Huselid, 1996; Snell and Dean, 1992; Solomon, 1992; Snell and wounded, 1995; MacDuffie, 1995; Yamamoto, 2011). Apart from financial incentives, many other sources also contribute to employee retention that include recognition of employee's achievement, encouraging innovation, work-life balance, communication process within organizations, organization's culture, Constituent attachments, Flexible work arrangements, Job satisfaction, Organizational commitment, Organizational justice, Organizational prestige, promotion, job security and designation (Yamamoto, 2011; Hausknecht et al., 2009; Kavitha, Geetha and Arunachalam, 2011; Jins, Joy, and Radhakrishnan, 2012; Hira and Naintara, 2011). Moreover, recent empirical evidence revealed that human resource management practices are contributing strongly in developing the employees' intentions to stay with the organization (Hussain et al., 2013; Deery et al., 2015).

\subsection{Impact of Human Resource Management Practices on Lecturer's Retention: Malaysian Perspective}

Very few studies have been conducted in the context of Malaysia regarding the influence of human resource management practices on employee retention and turnover intentions. Some studies highlight the importance of human resource management practices and identify major factors with respect to turnover intentions and employee retention.

For instance, a study by Darougheha et al. (2013) states that appropriate human resource practices in universities may increase job satisfaction that may affect organizational commitment and thereby turnover intention. Another study by Hong et al. (2012) identifies training, compensation and appraisal as major factors that impact retention decision of lecturers of Malaysian private universities. Whereas Rosdi and Harris (2011) find through their study that employee participation in decision-making, decentralization of authority, social interaction and employee security are the human resource management practices that are significant for 
organizational commitment among the academic staff of Malaysian private higher education institutes and thus lead to their retention. Another study by Morris, Yaacob and Wood (2004) provides evidence via attitudes and perceptions of lecturers that pay and promotion policies matter a lot in turnover intentions and thus vital to consider competitive policies in this regard to retaining the lecturers. Some suggestions are given regarding retention and loyalty of employees of Malaysian private higher education institutes in the study of Yussof, Ismail, and Osman (2011). According to them Malaysian private higher education institutes should provide training facilities to enhance employees competency, comfortable and good working environment to enhance employee's job satisfaction and loyalty, and should develop a good relationship among employees and employer that impact on employees personal traits such as work ethics, values and personality.

\subsection{Market Orientation}

Although an extensive research has been conducted regarding the relationship between market orientation and performance in companies (Dawes, 2000; Shoham et al., 2005; Kirca et al., 2005).

The role of market orientation in the tertiary sector has received attention recently. But the focus has been almost only on public universities (Caruana et al., 1998; Flavian and Lazano, 2006; Hampton et al., 2009) and business schools (Webster and Hammond, 2008). Whereas there has been very little or no research on the role of market orientation in private universities especially in the context of Malaysia. Outside Malaysia, very few researches have been done regarding market orientation and its impact on universities' performance. For instance, the results of the study conducted by Caruana et al (1998) on Australian and New Zealand universities confirm the positive relationship, which exists between market orientation and overall performance.

Another study done in Bangladesh by Zebal and Goodwin (2012) found a significant relationship between market orientation and performance of private universities of Bangladesh, however, this study suggested a potential research to be done regarding the relationship between market orientation and faculty retention that has not been studied so far. Thus, the present study will also aim to fill this gap by studying that if there is a significant relationship between market orientation and lecturer's retention in the context of Malaysia specifically.

Many studies support the fact that the implementation of market orientation in any organization will lead to superior business performance. For instance, three subsequent meta-analyses on market orientation have proven the positive relationship between market orientation and performance (Cano et al., 2004; Kirca et al., 2005; Shoham et al., 2005). These results have received further confirmation in a meta-analysis undertaken by Grinstein (2008).

According to $\mathrm{Qu}$ (2009), a market-oriented corporate culture should be embraced along with the efforts to enhance market-oriented activities to increase business performance. Whereas Narver and Slater (1990) stated that a strong market orientation would enhance the effort to offer superior value to the buyers which would lead towards competitive advantage as well as better profitability.

Positive customer responses result from the market orientation of organizations. Such responses can be identified as customer satisfaction and customer retention where the customers are more likely to repurchase a product or service when they feel satisfaction by buying them (Doyle, 1995). Kohli and Jaworski (1990) also argue that market orientation leads to satisfied customers who both recommend the product to other potential customers and keep repurchasing themselves. Market-oriented organizations are therefore expected to be of more benefit in contrast to those not adopting this orientation (Jogaratnam, 2017; M'zungu, Merrilees, and Miller, 2017). The results highlight the complex relationship between firm resources and performance and emphasize the need for understanding the market orientation situations for the possible competitiveness.

\subsection{Theoretical Contribution and Proposed Model}

The proposed model is based on the theory of market orientation proposed by Narver and Slater in 1990, who referred market orientation as the business culture that created necessary behaviors in response to the customer's needs. According to them the market orientation has three behavioral components that are customer orientation, competitor orientation, and inter-functional co-ordination as well as two decision criteria that are long-term focus and profitability.

But the proposed model is focusing more on customer orientation and competitor orientation. Customer orientation is defined as having sufficient understanding of customer's needs to create superior values continuously (Narver and Slater, 1990). Thus, organizations need to focus on current as well as future needs of their customers. Whereas through market orientation the organizations are able to understand the strengths, 
weaknesses, capabilities and strategies of their current and key potential competitors. Being market-oriented means that organizations are both customer-oriented and competitor-oriented (Narver and Slater, 1994).

Thus, on the basis of the theory of market orientation developed by Nerver and Slater in 1990, we may argue that private universities cannot retain their key internal customers (lecturers) without focusing on their current and future needs and without benchmarking of best practices by their competitors in this regard. Thus, the good human resource management practices become ineffective in the absence of these two key components of market orientation.

\section{Proposed Research Model}

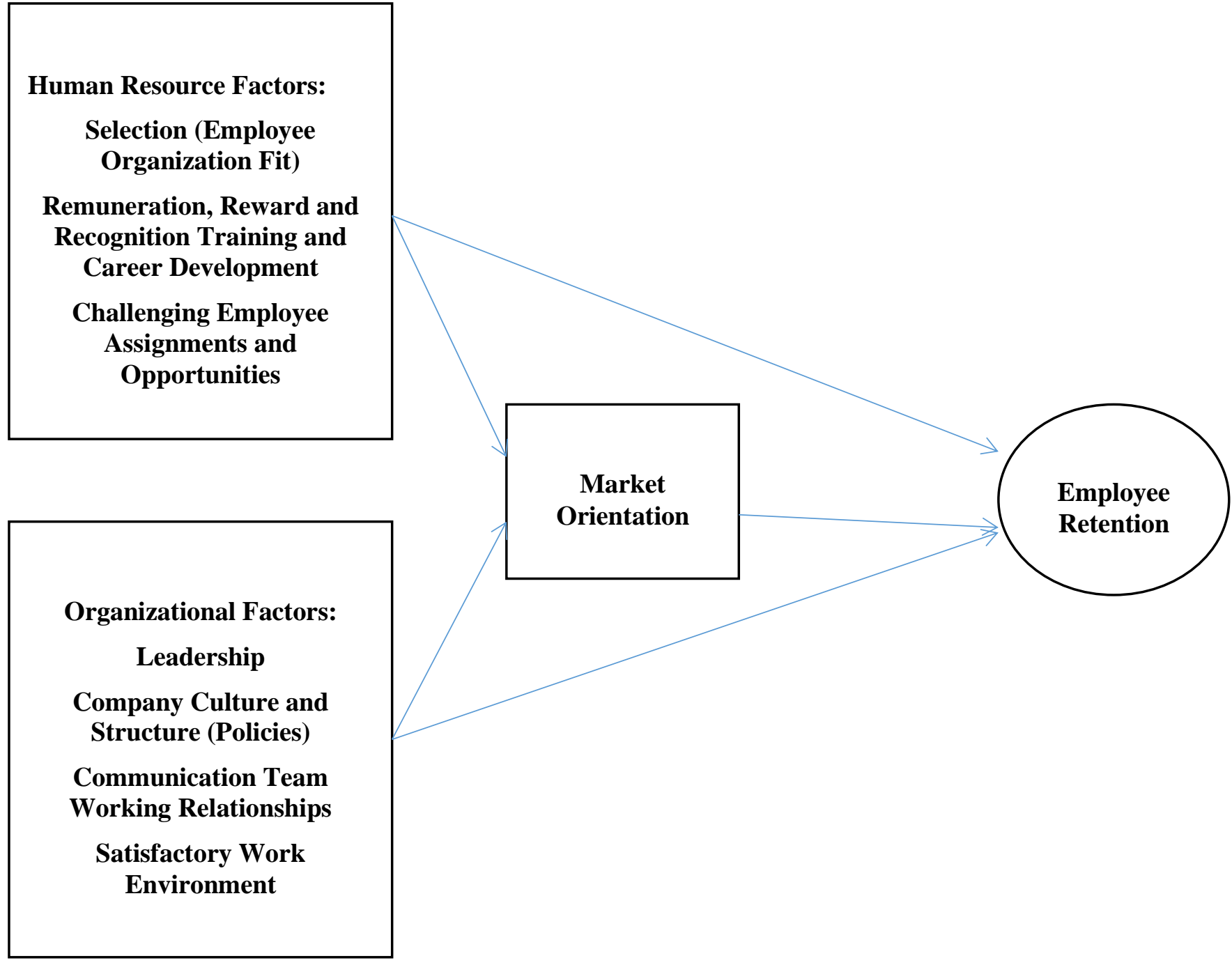

Figure 1. Conceptual Framework

The propositions of this research study are as follows:

Proposition 1: There is a relationship between human resource factors and employee retention.

Proposition 2: There is a relationship between organizational factors and employee retention.

Proposition 3: There is a relationship between human resource factors and market orientation.

Proposition 4: There is a relationship between organizational factors and market orientation.

Proposition 5: There is a relationship between market orientation and employee retention.

Proposition 6-a: The market orientation mediates the relationship between human resource factors and employee retention.

Proposition 6-b: The market orientation mediates the relationship between organizational factors and employee retention. 


\section{Contribution and Future Research}

This paper will help to revise retention policies regarding core lecturers of Malaysian private universities by considering market orientation as an essential mechanism. Thus, by introducing the theoretical framework, this paper emphasizes on the importance of market orientation in developing retention strategies. This paper provides guidelines with respect to core lecturer's retention strategies by reviewing the literature on human resource practices and market orientation. This paper emphasizes more on understanding current and future needs of key lecturers and on benchmarking best practices of competitor universities for retaining their core academic staff.

Since this is only a conceptual paper. Thus, the further study can test the model proposed in this paper. In addition, this paper provides some directions for further researches in the areas of retention policies. It recommends future researches to be conducted on market-oriented behavior and its impact on retention strategies in Malaysian public universities. Also, a comparison should be made among private and public universities of Malaysia regarding the effectiveness of market orientation on their performance. Furthermore, a new framework is needed to be developed to understand the impact of market orientation for achieving the sustainable competitive advantage by the universities.

\section{Conclusion}

In conclusion, this paper gives a comprehensive picture in regards human resource and market orientation to retention and this research study will be helpful in improving human resource strategies and policies regarding retention of core lecturers in Malaysian private universities by taking into consideration the two major components of market orientation that are customer orientation and competitor orientation. Through identifying the core lecturer's needs and actions of potential competitors, the private universities can devise more effective strategies to retain the core lecturers and will become more competitive in the education industry to achieve vision 2020 as well through the advancement of higher education. In addition, private universities will improve on their ranking, standard and quality of education because all these depend on highly qualified lecturers. The retention of such core lecturers will actually achieve overall objectives, which is not possible if core lecturers are not retained within private universities.

\section{References}

1. Ambrosius, J. (2018). Strategic talent management in emerging markets and its impact on employee retention: Evidence from Brazilian MNCs. Thunderbird International Business Review, 60(1), 53-68.

2. Amin, M. (2002). Tinjauan terhadap budaya pengurusan organisasi dan hubungan dengan hasilan perlakuan: Satu kajian kes di LandG, Master of Science thesis, Twintech Institute of Technology, Selangor.

3. Arthur, J. B. (1994). Effects of human resource systems on manufacturing performance and turnover. Academy of Management Journal, 37(3), 670-687.

4. Becker, B., Gerhart, B. (1996). The Impact of Human Resource Management on Organizational Performance: Progress and Prospects. The Academy of management Journal, 39(4), 779-801.

5. Beer, M. (1997). The transformation of the human resource function: Resolving the tension between a traditional administrative and a new strategic role. Human Resource Management, 36(1), 49-56.

6. Breuer, L. Nancy (2000). Even in high turnover industries, not everyone's a quitter, Retrieved from www.workforce.com/archive/feature/22/24/42/index.php.

7. Cano, C.R, Carrillat, F.A., Jaramillo, F. (2004). A meta-analysis of the relationship between market orientation and business performance: evidence from five countries. International Journal of Research in Marketing, 21(2), 179-200.

8. Caruana, A., Ramaseshan, B., and Ewing, M. T. (1998). Do universities that are more market orientated perform better? International journal of public sector management, 11(1), 55-70.

9. Caruana, A., Ramaseshan, B., and Ewing, M. T. (1998). The market orientation-performance link: some evidence from the public sector and universities. Journal of Nonprofit and Public Sector Marketing, 6(1), 63-82.

10.Darougheha, S., Pashandi, A.M., Hooman, A., Khanmohammadi, M. (2013). The impact of HR practices on Lecturers' Turnover Intention: A study of educational industry in Malaysia. Interdisciplinary journal of contemporary research in business, 4(9), 958-967. Retrieved from http://journalarchieves27.webs.com/958-967.pdf.

11.Davies, R. (2001). How to boost staff retention. In people management, 7(8), 54-55. 
12.Dawes, J. (2000). Market orientation and company profitability: further evidence, incorporating longitudinal data. Australian Journal of Management, 25(2), 173-199.

13.Deery, M., and Jago, L. (2015). Revisiting talent management, work-life balance and retention strategies. International Journal of Contemporary Hospitality Management, 27(3), 453-472.

14.Delaney, J. and Huseild, M. (1996). The impact of human resource management practices on perceptions of organizational performance. Academy of Management Journal, 39, 949-969.

15.Doyle, P. (1995). Marketing in the new millennium. European Journal of Marketing, 29(13), 23-41.

16.Fairholm, G.W. (1991). Values, Leadership: Toward a New Philosophy of Leadership, Praeger, New York, NY.

17.Fairholm, G.W. (1997). Capturing the Heart of Leadership: Spirituality and Community in the New American Workplace, Praeger, Westport, CT.

18.Ferris, G. R., Hochwarter, W. A., Buckley, M. R., Harrell-Cook, G., and Frink, D. D. (1999). Human resources management: Some new directions. Journal of Management, 25(3), 385-415.

19.Fitz-enz, J. (1990). Getting and keeping good employees. In personnel, 67(8), 25-28.

20.Flavián, C., and Lozano, J. (2006). Organisational antecedents of market orientation in the public university system. International Journal of Public Sector Management, 19(5), 447-467.

21.Grinstein, A. (2008). The relationships between market orientation and alternative strategic orientations: a meta-analysis. European Journal of Marketing, 42(1/2), 115-134.

22.Hampton, G. M., Wolk, M., Albinsson, P. A., and McQuitty, S. (2009). Market orientation and professionalism in higher education. Academy of Educational Leadership Journal, 13(1), 87-102.

23.Hausknecht, John P., Rodda, Julianne, Howard, Michael J. (2009). Targeted employee retention: Performance-based and job-related differences in reported reasons for staying. Human Resource Management, 48(2), 269-288.

24.Hays, S. W., and Kearney, R. C. (2001). Anticipated changes in human resource management: Views from the field. Public Administration Review, 61(5), 585-597.

25.Hong, E. N. C., Ramendran, C., Hao, L. Z., Kumar, R., and Kadiresan, V. (2012). An Effectiveness of Human Resource Management Practices on Employee Retention in Institute of Higher learning: - A Regression Analysis. International Journal of Business Research and Management (IJBRM), 3(2), 60-79.

26.Hussain, T., and Rehman, S. S. (2013). Do human resource management practices inspire employees' retention? Research Journal of Applied Sciences, Engineering and Technology, 6(19), 3625-3633.

27.Jackson, S. E., and Schuler, R. S. (1995). Understanding human resource management in the context of organizations and their environments. Strategic Human Resource Management, 46, 237-264.

28.Jins, Joy P., Radhakrishnan, R.(2012). Changing Jobs: Influencing Factors. SCMS Journal of Indian Management, 9(1), 59-68.

29.Jogaratnam, G. (2017). The effect of market orientation, entrepreneurial orientation and human capital on positional advantage: evidence from the restaurant industry. International Journal of Hospitality Management, 60, 104-113.

30.Kavitha, S. R., Geetha, S. R., Arunachalam, V. (2011). An Empirical Study on Employee Retention Strategies in a Biscuit Manufacturing Company in India. Interdisciplinary Journal of Contemporary Research in Business, 3(4), 762-772.

31.Kirca, A. H., Jayachandran, S., and Bearden, W. O. (2005). Market orientation: a meta-analytic review and assessment of its antecedents and impact on performance. Journal of marketing, 69(2), 24-41.

32.Koch, M. J., and McGrath, R. I. T. A. (1996). Improving labor productivity: Human resource management policies do matter. Strategic Management Journal, 17(5), 335-354.

33.Kohli, A. K., and Jaworski, B. J. (1990). Market orientation: the construct, research propositions, and managerial implications. The Journal of Marketing, 54(2), 1-18.

34.Kouzes, J.M., Posner, B.Z. (1987). The Leadership Challenge, Jossey-Bass, San Francisco, CA.

35.Lenn, M. P. (2000). Higher education and the global marketplace: A practical guide to sustaining quality. On the Horizon, September/October, 7-10.

36.M'zungu, S., Merrilees, B., and Miller, D. (2017). Strategic hybrid orientation between market orientation and brand orientation: guiding principles. Journal of Strategic Marketing, 25(4), 275-288.

37. MacDuffie, J. P. (1995). Human resource bundles and manufacturing performance: Organizational logic and flexible production systems in the world auto industry. Industrial and labor relations review, 48, 197-221.

38.Mintzberg, H. (1977). The Nature of Managerial Work, Harper and Row, New York, NY.

39.Morris, D., Yaacob, A., and Wood, G. (2004). Attitudes towards pay and promotion in the Malaysian higher educational sector. Employee Relations, 26(2), 137-150. Doi:10.1108/01425450410511052.

40.Narver, J. C., and Slater, S. F. (1990). The effect of a market orientation on business profitability. The Journal of Marketing, 54(4), 20-35. 
41.Oakland, S., and Oakland, J. S. (2001). Current people management activities in world-class organizations. Total Quality Management, 12(6), 773-788.

42.Perry-Smith, J. E., and Blum, T. C. (2000). Work-family human resource bundles and perceived organizational performance. Academy of Management Journal, 43(6), 1107-1117.

43.Pfeffer, J. (1996). Competitive advantage through people: Unleashing the power of the work force. Harvard Business Press.

44.Pfeffer, J. (1998). The Human Equation. Journal Business, 13(2), 55.

45.Qu, R. (2009). The impact of market orientation and corporate social responsibility on firm performance: evidence from China. Asia Pacific Journal of Marketing and Logistics, 21(4), 570-582.

46.Rosdi, I. S., and Harris, H. (2011). Human resource management practices and organizational commitment : the case of academics in a Malaysian higher education institution. 2nd international conference on business and economic research (2nd icber 2011) proceeding (pp. 1155-1173).

47.Shoham, A., Rose, G. M., and Kropp, F. (2005). Market orientation and performance: a meta-analysis. Marketing Intelligence and Planning, 23(5), 435-454.

48.Siron, A. (2005). Komitmen pensyarah Institusi pendidikan swasta bertaraf universiti terhadap organisasi, Tesis kedoktoran falsafah, UPM, Serdang.

49.Snell, S. A., and Dean Jr, J. W. (1992). Integrated manufacturing and human resource management: A human capital perspective. Academy of Management journal, 467-504.

50.Snell, S. A., and Youndt, M. A. (1995). Human resource management and firm performance: Testing a contingency model of executive controls. Journal of Management, 21(4), 711-737.

51.Solomon, C.M. (1992). The loyalty factor. Personnel journal, 52, 32-37.

52. Tsui, A. S., Pearce, J. L., Porter, L. W., and Tripoli, A. M. (1997). Alternative approaches to the employeeorganization relationship: does investment in employees pay off? Academy of Management Journal, 1089-1121.

53.Van Berkel, R., Ingold, J., McGurk, P., Boselie, P., and Bredgaard, T. (2017). Editorial introduction: An introduction to employer engagement in the field of HRM. Blending social policy and HRM research in promoting vulnerable groups' labour market participation. Human Resource Management Journal, 27(4), 503-513.

54.Webster, R.L., Hammond, K.L. (2008), Does a market orientation strategy exist toward business school students? A view from three levels of academic administrators. Academy of Marketing Studies Journal, 12(2), 19-33.

55.Wright, P. M., McMahan, G. C., and McWilliams, A. (1994). Human resources and sustained competitive advantage: a resource-based perspective. International Journal of Human Resource Management, 5(2), 301-326.

56. Yamamoto, H. (2011). The relationship between employee benefit management and employee retention. International Journal of Human Resource Management, 22(17), 3550-3564.

57.Yussof, I., Ismail, R., and Osman, Z. (2011). Workers' Competency, Performance and Competitiveness in Malaysia's Private Education Sector. Jurnal Ekonomi Malaysia, 45, 61-70.

58.Zebal, M. A., and Goodwin, D. R. (2012). Market orientation and performance in private universities. Marketing Intelligence and Planning, 30(3), 339-357. 